\title{
IN ARCHAEOLOGICAL PRACTICE
}

A Journal of the Society for American Archaeology

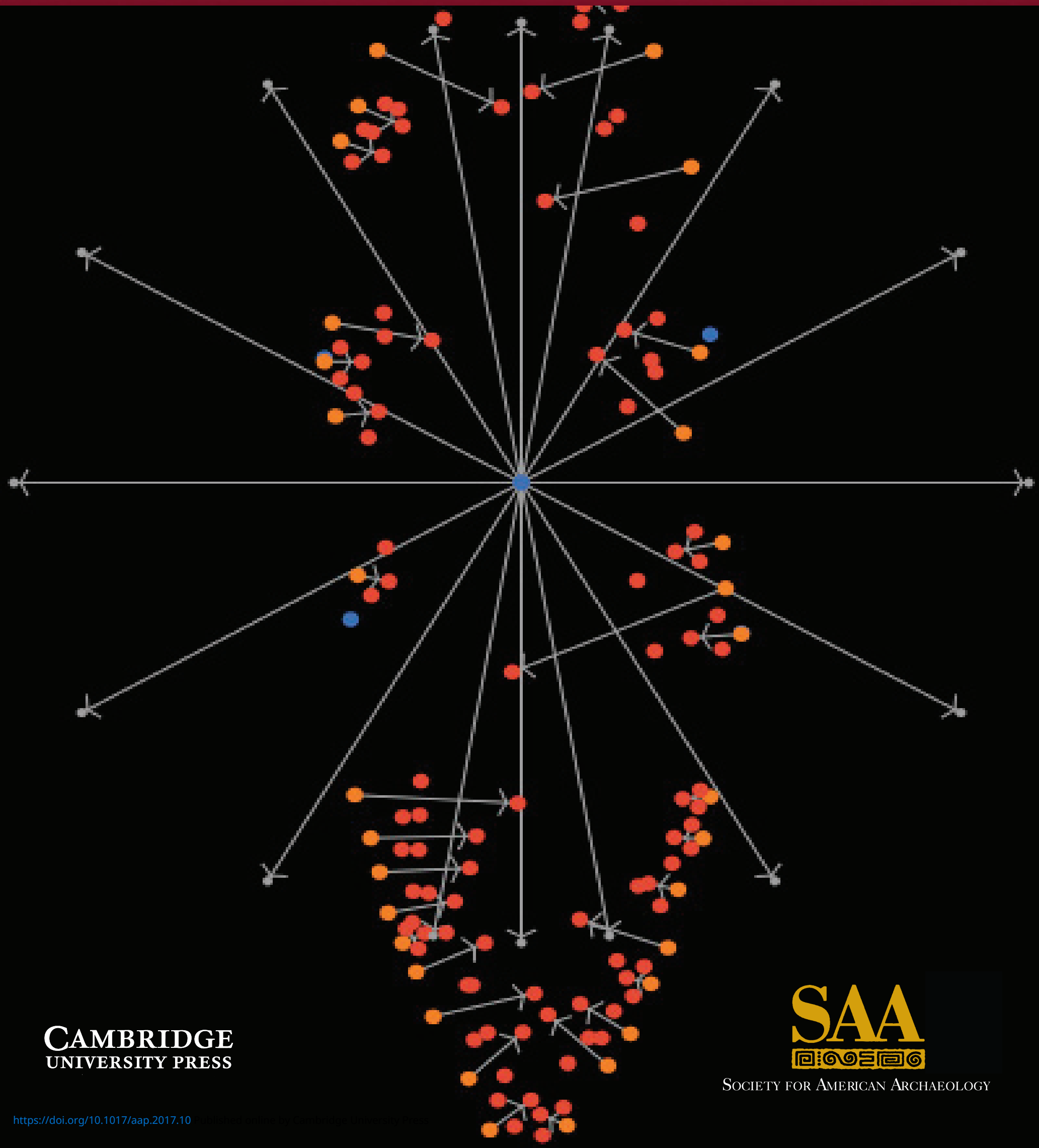




\title{
IN ARCHAEOLOGICAL PRACTICE
}

\section{A Journal of the Society for American Archaeology}

\author{
Volume 5, No.2 $\mathbf{a}$ May 2017
}

\section{RESEARCH}

110-124 The Role of Magnetometry in Managing Arctic Archaeological Sites in the Face of Climate Change

Lisa M. Hodgetts and Edward J. H. Eastaugh

125-137 Estimating the Magnitude of Private Collection of Points and Its Effects on Professional Survey Results: A Michigan Case Study

Michael J. Shott

138-146 The Potential and Pitfalls of Large Multi-Source Collections: Insights from the Analysis of Mimbres Gender Imagery

Michelle Hegmon, James R. McGrath, and Marit K. Munson

147-158 Minimally Invasive Research Strategies in Huron-Wendat Archaeology: Working toward a Sustainable Archaeology

Bonnie Glencross, Gary Warrick, Edward Eastaugh, Alicia Hawkins, Lisa Hodgetts, and Louis Lesage

159-169 Social Networks and Networked Scholars: An Open-Access Database of Paddle Designs from Pottery of the Woodland Period in the American Southeast

Thomas J. Pluckhahn and Neill J. Wallis

170-183 Strategies for ${ }^{14} \mathrm{C}$ Dating the Oxtotitlán Cave Paintings, Guerrero, Mexico Jon Russ, Mary D. Pohl, Christopher L. von Nagy, Karen L. Steelman, Heather Hurst, Leonard Ashby, Paul Schmidt, Eliseo F. Padilla Gutiérrez, and Marvin W. Rowe

184-195 Why a Standardization of Strontium Isotope Baseline Environmental Data Is Needed and Recommendations for Methodology

Deanna N. Grimstead, Selin Nugent, and Jean Whipple

196-205 Paleoethnobotanical Sampling Adequacy and Ubiquity: An Example from the American Southwest

Michael W. Diehl

\section{HOW-TO}

206-213 Data Considerations when Teaming with Avocational Detectorists

Christopher T. Espenshade

\section{DIGITAL REVIEW}

214-219 "From the Stone Age to the Information Age": History and Heritage in Sid Meier's Civilization VI

Angus A.A. Mol, Aris Politopoulos, and Csilla E. Ariese-Vandemeulebroucke 


\section{IN ARCHAEOLOGICAL PRACTICE}

\section{A Journal of the Society for American Archaeology}

EDITOR: SARAH A. HERR, Desert Archaeology, Inc., 3975 N. Tucson Blvd., Tucson, AZ 85716; phone: 520-881-2244;

aap_herr@desert.com

EDITOR: CHRISTINA B. RIETH, New York State Museum, Division of Research and Collections, Cultural Education Center 3118, Albany, NY 12230

ASSOCIATE EDITOR: SJOERD VAN DER LINDE, CommonSites, Spaarndammerstraat 57-2, 1013TA Amsterdam,

The Netherlands; phone: +31655137680; sjoerd@commonsites.net

DIGITAL REVIEWS EDITOR: SARA PERRY, Department of Archaeology, University of York, The King's Manor, York, YO1 7EP, United Kingdom; phone: (44) 1904 323907; sara.perry@york.ac.uk

MANAGING EDITOR: MAYA ALLEN-GALLEGOS, Society for American Archaeology, 1111 14th Street NW, Suite 800, Washington, DC 20005; phone: 202-559-5750; maya_allen-gallegos@saa.org

\section{EDITORIAL BOARD}

Kimball Banks, Metcalf Archaeological Consultants, Inc.

S. Terry Childs, U.S. Department of the Interior

Robert Connolly, University of Memphis, C.H. Nash Museum

Lynne Goldstein, Michigan State University

Gaygysyz Joraev, University College London, Institute of Archaeology

David Killick, University of Arizona

Ian Lilley, University of Queensland

Owen Lindauer, Federal Highway Administration

César Méndez Melgar, Universidad de Chile
Tomás Mendizábal, Independent Consultant

William Moss, Ville de Quebec

Seetha Reddy, Reddy Anthropology Consulting

Torben Rick, Smithsonian Institution

Jason Ur, Harvard University

Monique van den Dries, Leiden University

Gerry Wait, Nexus Heritage

John R. Welch, Simon Fraser University

Advances in Archaeological Practice is a quarterly, full-color, digital journal devoted to sharing creative solutions to challenges in the practice of archaeology globally. The journal is available as a benefit of membership in the SAA or by subscription. 